\title{
Nutritional and anti nutritional assessment of under utilized legume D. lablab var. vulgaris $\mathrm{L}$.
}

\author{
V. Kalpanadevi and V. R. Mohan* \\ Ethnopharmacology Unit, Research Department of Botany, V.O.Chidambaram College, Tuticorin-628008, Tamil
}

Nadu, India

\begin{abstract}
Two samples of seed materials of the under utilized tribal pulse, D. lablab var. vulgaris (dark brown and pale brown coloured seed coat) were collected from Anakodi, Krishnagiri district, Eastern Ghats, Tamil Nadu. The mature seed samples were analysed for proximate composition, mineral profiles, vitamins, seed protein fractions, fatty acid profiles, amino acid profiles and antinutritional factors. The investigated seed samples of $D$. lablab var. vulgaris contained higher amounts of crude protein and crude lipid when compared with most of the commonly consumed pulses. The investigated seeds were rich in minerals such as $\mathrm{Na}, \mathrm{K}, \mathrm{P}, \mathrm{Ca}, \mathrm{Mg}$ and Fe. Albumin and globulin fractions constituted the major bulk of seed protein. The essential amino acid profiles of total seed proteins were compared favourably with FAO/WHO (1991) requirement pattern. The fatty acid profiles of both the samples revealed that the seed lipids contained higher concentration of unsaturated fatty acids (66.78-69.08\%) and had very high contents of linoleic acid (40.36-41.62\%). Antinutrtional factors like total free phenolics, tannins, L-DOPA, phytic acid, hydrogen cyanide, trypsin inhibitor, oligosaccharides (raffinose, stachyose, verbascose) and phytohaemagglutinating activity were analyzed.
\end{abstract}

Keywords: D. lablab var. vulgaris; Vitamins; Protein fractions; Fatty acids profiles; Amino acids; Antinutritional factors

\section{Introduction}

Legumes with high protein content, energy values, vitamin and mineral content, have been recognized as "meat of poor people" (Bello-Perez et. al., 2007). The increasing global protein consumption and high prices for meat and fish have led to the demand for new food protein sources, particularly from plants. With increasing in new food sources, the seeds of wild plants, including the tribal pulses, are receiving more attention because they are well adapted to adverse environmental conditions, highly resistant to disease and pests and exhibit good nutritional qualities (Maikhuri et. al., 1991). There are some 28 wild legumes commonly consumed by different tribal seeds of India (Arora et. al., 1980; Arinathan et. al., 2009). However, most of the underutilized legumes/tribal pulses remain uninvestigated biochemically and nutritionally. The tribal communities living in the forest of Eastern Ghats, Krishnagiri, Tamil Nadu, collected the seeds of underutilized legumes from the vicinity of the forests and consumed the seed after boiling. This was tempted to study the nutritional and antinutritional composition of the underutilized legumes for its potential use in human nutrition. In this context, in the present investigation, an attempt has been made to understand the chemical composition and antinutritional factors of the tribal pulses to suggests ways and means to remove the antinutritional/toxins and make the edible plants safe protein sources for mass consumption. Therefore, this study was designed to evaluate the nutritional and antinutritional properties of underutilized legume Dolichos lablab var. vulgaris.

\section{Materials and methods}

\section{Collection of seed samples}

The seeds of Dolichos lablab var. vulgaris (dark brown and pale brown coloured seed coat) were collected in wild conditions during the month of August 2011 from Anakodi, Krishnagiri district, Eastern Ghats, Tamil Nadu. With the help of local flora, the plants were botanically identified. The collected pods were thoroughly sun dried, the pods were thrashed to remove seeds. Broken seeds, foreign materials and immature seeds were removed, followed by thorough cleaning and storage in an air tight plastic jar at room temperature $\left(25^{\circ} \mathrm{C}\right)$.

\footnotetext{
*Corresponding author. e-mail: vrmohan_2005@yahoo.com
} 


\section{Proximate composition}

\section{Moisture and crude protein}

The moisture content was determined by drying 50 transversely cut seed in an oven at $80^{\circ} \mathrm{C}$ for $24 \mathrm{hr}$ and is expressed on a percentage basis. The air-dried samples were powdered separately in a Wiley mill (Scientific Equipment, Delhi, India) to 60-mesh size and stored in screw capped bottles at room temperature for further analysis.

The nitrogen content was estimated by the micro-Kjeldahl method (Humphries, 1956) and the crude protein content was calculated $(\mathrm{N} \times 6.25)$.

\section{Crude lipid and ash}

Crude lipid content was determined using Soxhlet apparatus (AOAC, 2005).The ash content was determined by heating $2 \mathrm{~g}$ of the dried sample in a silica dish at $600^{\circ} \mathrm{C}$ for $6 \mathrm{hr}$ (AOAC, 2005).

\section{Total dietary fibre}

Total dietary fibre (TDF) was estimated by the non-enzymatic-gravimetric method ( $\mathrm{Li}$ and Cardozo, 1994). To determine the TDF, duplicate $500 \mathrm{mg}$ ground samples were taken in separate $250 \mathrm{~mL}$ beakers. To each beaker $25 \mathrm{~mL}$ water was added and gently stirred until the samples were thoroughly wetted, (i.e. no clumps were noticed). The beakers were covered with $\mathrm{Al}$ foil and allowed to stand $90 \mathrm{~min}$ without stirring in an incubator maintained at $37^{\circ} \mathrm{C}$. After that, $100 \mathrm{~mL}$ $95 \%$ ethanol was added to each beaker and allowed to stand for $1 \mathrm{hr}$ at room temperature $\left(25 \pm 2^{\circ} \mathrm{C}\right)$. The residue was collected under vacuum in a pre-weighed crucible containing filter aid. The residue was washed successively with $20 \mathrm{~mL}$ of $78 \%$ ethanol, $10 \mathrm{~mL}$ of $95 \%$ ethanol and $10 \mathrm{~mL}$ acetone. The crucible containing the residue was dried for $\geq 2 \mathrm{hr}$ at $105^{\circ} \mathrm{C}$ and then cooled for $\geq 2 \mathrm{hr}$ in a desiccator and weighed. One crucible containing residue was used for ash determination at $525^{\circ} \mathrm{C}$ for $5 \mathrm{hr}$. The ash-containing crucible was cooled for $\geq 2 \mathrm{hr}$ in a desiccator and weighed. The residue from the remaining duplicate crucible was used for crude protein determination by the micro-Kjeldahl method as already mentioned. The TDF was calculated as follows.

$$
\mathrm{TDF} \%=100 \times \frac{W r-[(P+A) / 100]}{W r}
$$

Where $W r$ is the $\mathrm{mg}$ residue, $P$ is the $\%$ of protein in the residue; $A$ is the $\%$ ash in the residue, and $W S$ is the mg sample.

\section{Nitrogen free extractives}

The nitrogen free extract (NFE) was obtained by difference (Muller and Tobin, 1980).

\section{Calorific value}

The energy value of the seed $(\mathrm{kJ})$ was estimated by multiplying the percentages of crude protein, crude lipid and NFE by the factors 16.7, 37.7 and 16.7, respectively (Siddhuraju et. al., 1996).

\section{Minerals and vitamins analysis}

Five hundred milligrams of the ground legume seed was digested with a mixture of $10 \mathrm{~mL}$ concentrated nitric acid, $4 \mathrm{~mL}$ of $60 \%$ perchloric acid and $1 \mathrm{~mL}$ of concentrated sulphuric acid. After cooling, the digest was diluted with $50 \mathrm{~mL}$ of deionised distilled water, filtered with Whatman No. 42 filter paper and the filtrates were made up to $100 \mathrm{~mL}$ in a glass volumetric flask with deionised distilled water. All the minerals except phosphorus were analysed from a triple acid-digested sample by an atomic absorption spectrophotometer - ECIL (Electronic Corporation of India Ltd., India) (Issac and Johnson, 1975). The phosphorus content in the triple acid digested extract was determined colorimetrically (Dickman and Bray, 1940).

Ascorbic acid and niacin contents were extracted and estimated as per the method given by (Sadasivam and Manickam, 1996). For the extraction of ascorbic acid, $3 \mathrm{~g}$ airdried powdered sample was ground with $25 \mathrm{~mL}$ of $4 \%$ oxalic acid and filtered. Bromine water was added drop by drop to $10 \mathrm{~mL}$ of the filtrate until it turned orange-yellow to remove the enolic hydrogen atoms. The excess of bromine was expelled by blowing in air. This filtrate was made up to $25 \mathrm{~mL}$ with $4 \%$ oxalic acid and used for ascorbic acid estimation. Two millilitres of the extract was made up to $3 \mathrm{~mL}$ with distilled $\mathrm{H}_{2} \mathrm{O}$ in a test tube. One millilitre of $2 \% 2,4$ dinitrophenyl hydrazine reagent and a few drops of thiourea were added. The contents of the test tube were mixed thoroughly. After $3 \mathrm{hr}$ incubation at $37^{\circ} \mathrm{C}, 7 \mathrm{~mL}$ of $80 \% \mathrm{H}_{2} \mathrm{SO}_{4}$ was added to dissolve the osazone crystals and the absorbance was measured at $540 \mathrm{~nm}$ against a reagent blank. For the extraction of niacin, $5 \mathrm{~g}$ air-dried powdered sample was steamed with $30 \mathrm{ml}$ concentrated $\mathrm{H}_{2} \mathrm{SO}_{4}$ for $30 \mathrm{~min}$. After cooling, this suspension was made up to $50 \mathrm{ml}$ with distilled $\mathrm{H}_{2} \mathrm{O}$ and filtered. Five millilitres of $60 \%$ basic lead acetate was added to $25 \mathrm{~mL}$ of the filtrate. The $\mathrm{pH}$ was adjusted to 9.5 and centrifuged to collect the supernatant. Two millilitres of concentrated $\mathrm{H}_{2} \mathrm{SO}_{4}$ was added to the 
supernatant. The mixture was allowed to stand for $1 \mathrm{hr}$ and centrifuged. The $5 \mathrm{~mL}$ of $40 \% \mathrm{ZnSO}_{4}$ was added to the supernatant. The $\mathrm{pH}$ was adjusted to 8.4 and centrifuged again. Then the $\mathrm{pH}$ of the collected supernatant was adjusted to 7 and used as the niacin extract. For estimation, $1 \mathrm{mLextract}$ was made up to $6 \mathrm{~mL}$ with distilled water in a test tube, $3 \mathrm{~mL}$ cyanogen bromide was added and shaken well, followed by addition of $1 \mathrm{~mL}$ of $4 \%$ aniline. The yellow colour that developed after 5 min was measured at 420 $\mathrm{nm}$ against a reagent blank. The ascorbic acid and niacin contents present in the sample were calculated by referring to a standard graph and expressed as milligrams per $100 \mathrm{~g}$ of powdered samples.

\section{Lipid extraction and fatty acid analysis}

The total lipid was extracted from the seeds according to the method of (Folch et. al., 1957) using chloroform and methanol mixture in ratio of 2: $1(\mathrm{v} / \mathrm{v})$. Methyl esters were prepared from the total lipids by the method of (Metcalfe et. al., 1966). Fatty acid analysis was performed by gas chromatography (ASHMACO, Japan; Model No: ABD20A) using an instrument equipped with a flame ionization detector and a glass column $(2 \mathrm{~m} \times 3 \mathrm{~mm})$ packed with $1 \%$ diethylene glycol succinate on chromosorb $\mathrm{W}$. The temperature conditions for $\mathrm{GC}$ were injector $200^{\circ} \mathrm{C}$ and detector $210^{\circ} \mathrm{C}$. The temperature of the oven was programmed from $180^{\circ} \mathrm{C}$ and the carrier gas was nitrogen at a flow rate of $30 \mathrm{ml} / \mathrm{min}$. Peaks were identified by comparison with authentic standards, quantified by peak area integration and expressed as weight percentage of total methyl esters; the relative weight percentage of each fatty acid was determined from integrated peak areas.

\section{Amino acid analysis}

The total seed protein was extracted by a modified method of (Basha et. al., 1976). The extracted proteins were purified by precipitation with cold $20 \%$ trichloroacetic acid (TCA). A protein sample of $30 \mathrm{mg}$ was hydrolysed by $6 \mathrm{~N}$ HCL $(5 \mathrm{~mL})$ in an evacuated sealed tube, which was kept in an air oven maintained at $110^{\circ} \mathrm{C}$ for $24 \mathrm{hr}$. The sealed tube was broken and the acid removed completely by repeated flash evaporation after the addition of de-ionized water. Dilution was effected by means of citrate buffer $\mathrm{pH} 2.2$ to such an extent that the solution contained $0.5 \mathrm{mg}$ protein $\mathrm{ml}^{-1}$. The solution was passed through a millipore filter $(0.45 \mu \mathrm{M})$ and derivitized with O-phthaldialdehyde by using an automated precolumn (OPA). Aminoacids were analysed by a reverse phase HPLC (Method L 7400, HITACHI, Japan) fitted with a denali $\mathrm{C} 185$ micron column $(4.6 \times 150 \mathrm{~mm})$. The flow rate was $1 \mathrm{~mL}$ per min with fluorescence detector. The cystine content of protein sample was obtained separately by the (Liddelle and Saville, 1959) method. For the determination of tryptophan content of proteins, aliquots containing known amounts of proteins were dispersed into glass ampoules together with $1 \mathrm{~mL} 5 \mathrm{M} \mathrm{NaOH}$. The ampoules were flame sealed and incubated at $110^{\circ} \mathrm{C}$ for $18 \mathrm{hr}$. The tryptophan contents of the alkaline hydrolysates were determined colorimetrically using the method of (Spies and Chambers, 1949) as modified by (Rama Rao et. al., 1974). The contents of the different amino acids (AA) were expressed as g/100g proteins and were compared with FAO/WHO (1991) reference pattern. The essential amino acid score was calculated as follows:

Essential AA score $=$

Essential AA in $\mathrm{g} / 100 \mathrm{~g}$ of total protein $\times 100$

Essential AA in $g / 100 \mathrm{~g}$ of $\mathrm{FAO} / \mathrm{WHO}$ (1991) reference pattern

\section{Analysis of antinutritional compounds}

The antinutritional compounds, total free phenolics (Bray and Thorne, 1954), tannins (Burns, 1971), the non-protein amino acid, L-DOPA (3, 4-dihydroxyphenylalanine) (Brain, 1976), phytic acid (Wheeler and Ferrel, 1971) and hydrogen cyanide (Jackson, 1967) were quantified. Trypsin inhibitor activity was determined by the enzyme assay of (Kakade et. al., 1974) by using benzoil-DL-arginin-p-nitroanilide (BAPNA) as a substrate. One trypsin inhibitor unit (TIU) has been expressed as an increase of 0.01 absorbance units per $10 \mathrm{ml}$ of reaction mixture at $410 \mathrm{~nm}$. Trypsin inhibitor activity has been defined in terms of trypsin units inhibited per mg protein.

\section{Estimation of oligosaccharides}

Extraction of oligosaccharides was done following the method of (Somiari and Balogh, 1993). Five grams each of all the samples of seed flours were extracted with $50 \mathrm{~mL}$ of $70 \%(\mathrm{v} / \mathrm{v})$ aqueous ethanol and kept on an orbital shaker at $130 \mathrm{rpm}$ for $13 \mathrm{hr}$ and then filtered through Whatman No. 1 filter paper. Residue was further washed with $25 \mathrm{~mL}$ of $70 \%$ $(\mathrm{v} / \mathrm{v})$ ethanol. The filtrates obtained were pooled and vacuum-dried at $45^{\circ} \mathrm{C}$. The concentrated sugar syrup was dissolved in five $\mathrm{mL}$ of double-distilled water. Separation of oligosaccharides was done by TLC. Thirty g of cellulose-G powder were dissolved in $45 \mathrm{ml}$ of double distilled water and shaken well until the slurry was homogeneous. TLC plates were coated with the slurry and air-dried. Spotting of the 
sugar samples was done by using micropipettes. Five $\mu \mathrm{L}$ aliquots of each sample were spotted thrice separately. The plates were developed by using a solvent system of npropanol, ethyl acetate and distilled water (6:1:3), and dried (Tanaka et. al., 1975). The plates were sprayed with $\alpha$-naphthol reagent $(1 \%, w / v)$. Plates were dried in a hot-air oven. The separated spots were compared with standard sugar spots. A standard sugar mixture containing raffinose, stachyose and verbascose (procured from sigma chemical co., St. Louis, USA). Separated sugars that appeared were verbascose, stachyose and raffinose. The sugar spots were scrapped, eluted in $2 \mathrm{~mL}$ of distilled water kept overnight and filtered through Whatman No. 1 filter paper. The filtrates were subjected to quantitative estimation. The eluted individual oligosaccharides were estimated by the method of (Tanaka et. al., 1975). One $\mathrm{mL}$ of the eluted and filtered sugar solution was treated with one $\mathrm{ml}$ of $0.2 \mathrm{M}$ thiobarbituric acid and one $\mathrm{ml}$ of concentrated $\mathrm{HCl}$. The tubes were boiled in a water bath for exactly $6 \mathrm{~min}$. After cooling, the oligosaccharide contents were quantified in an Elico UVSpectrophotometer model SL 150 at $432 \mathrm{~nm}$. Average values of triplicate estimations were calculated and the content of oligosaccharides was expressed on dry weight basis.

\section{Determination of phytohaemagglutinating (Lectin) activity}

Lectin activity was determined by the method of (Almedia et. al., 1991). One g of air-dried seed flour was stirred with $10 \mathrm{ml}$ of $0.15 \mathrm{~N}$ sodium chloride solution for 2 hours and the $\mathrm{pH}$ was adjusted to 4.0. The contents were centrifuged at $10,000 \mathrm{x} \mathrm{g}$ for $20 \mathrm{~min}$. and the supernatants were collected separately. The protein content was estimated by the (Lowry et. al., 1951) method. Human blood (blood groups A, B and O) was procured from the blood bank of Jothi Clinical Laboratory, Tuticorin.

Blood erythrocyte suspensions were prepared by washing the blood samples separately with phosphate-buffered saline and centrifuged for $3 \mathrm{~min}$ at low speed. Supernatants were removed with Pasteur pipettes. The washing procedure was repeated three times. The washed cells were diluted by one drop of cells with 24 drops of phosphate - buffered saline.

The determination of lectin was done by the method of Tan et. al., (1983). Clear supernatant $(50 \mu \mathrm{L})$ was poured into the depression (pit) on a micro-titration plate and serially diluted 1:2 with normal saline. The human blood erythrocyte (A, $\mathrm{B}$ and $\mathrm{O}$ blood groups) suspensions $(25 \mu \mathrm{L})$ were added to each of the twenty depressions. The plates were incubated for 3 hours at room temperature. After the incubation period, the titre values were recorded. One haemagglutinating unit (HU) is defined as the least amount of haemagglutinin that will produce positive evidence of agglutination of $25 \mu \mathrm{L}$ of a blood group erythrocyte after $3 \mathrm{hr}$ incubation at room temperature. The phytohaemagglutinating activity was expressed as haemagglutinating units (HU) / mg protein.

\section{Determination of in vitro protein digestibility (IVPD)}

This was determined using the multi-enzyme technique (Hsu et. al., 1977). The enzymes used for IVPD were purchased from Sigma Chemical Co., St. Louis, MO, USA. Calculated amounts of the control (casein) and sample were weighed out, hydrated in $10 \mathrm{~mL}$ of distilled water and refrigerated at $5^{\circ} \mathrm{C}$ for $1 \mathrm{~h}$. The samples containing protein and enzymes were all adjusted to $\mathrm{pH} 8.0$ at $37^{\circ} \mathrm{C}$. The IVPD was determined by the sequential digestion of the samples containing protein with a multi-enzyme mixture (trypsin, oo-chymotrypsin and peptidase) at $37^{\circ} \mathrm{C}$ followed by protease at $55^{\circ} \mathrm{C}$. The $\mathrm{pH}$ drop of the samples from $\mathrm{pH} 8.0$ was recorded after 20min of incubation. The IVPD was calculated according to the regression equation $Y=234.84-22.56 X$, where $Y$ is the $\%$ digestibility and $X$ the $\mathrm{pH}$ drop.

\section{Statistical analysis}

Proximate composition of minerals, vitamins (niacin and ascorbic acid), antinutritional factors like total free phenolics, tannins, L-DOPA, phytic acid, hydrogen cyanide and oligosaccharides were estimated in triplicate determinations. Data were analyzed using the statistical analysis system SPSS (SPSS software for windows release 17.5; SPSS Inc., Chicago IL, USA) Estimates of mean, standard error for aforesaid parameters were calculated.

\section{Results and discussion}

The proximate composition of Dolichos lablab var. vulgaris are shown in the Table I. The crude protein content of Dolichos lablab var. vulgaris is higher than the commonly consumed legumes Cicer arietinum (Srivastava and Ali, 2004; Khatoon and Prakash, 2006); tribal pulses like Dolichos trilobus, Rhynchosia cana, R. shaveolens, Vigna radiata var. sublobata, $V$. unguiculata subsp. cylindrical (12.8 - $18.5 \mathrm{~g} / 100 \mathrm{gm})$ (Arinathan et. al., 2009) and Lablab purpuries var. $\mathrm{CO}_{12}$ (Kala et. al., 2010). The remarkably high level of protein in the wild legume under study underscores their importance as source of this vital nutrient. Similarly both the seed samples of Dolichos lablab var. vulgaris contained higher lipids than those in other tribal pulses, Vigna aconitifolia and $V$. unguiculata subsp. unguiculata (Maroon coloured seed coat) (Tresina and Mohan, 2011). 
The high NFE content of Dolichos lablab var. vulgaris (both the samples) enable this legume to act as a good source of calories which would be antimarasmus, especially infant nutrition (Vadivel and Janardhanan, 2000). The range in calorific values (1606.08-1609.21 KJ 100 $\left.{ }^{-1} \mathrm{DW}\right)$ exceeds energy value of cowpea, green gram, horse gram, moth bean and peas (Rao et. al., 1989) which are in the range of 1318$1394 \mathrm{KJ}^{100 \mathrm{~g}^{-1} \mathrm{DW}}$.
Food legumes are a good source of minerals such as calcium, iron, copper, Zinc, potassium and magnesium (Salunkhe et. al., 1985). Table II showed the mineral composition of the seed samples of Dolichos lablab var. vulgaris registered a higher level of potassium when compared with recommended dietary allowance value of infants and children $(<1550$ $\mathrm{mg}$ ) (NRC/NAS 1980). The high content of potassium can be utilized beneficially in the diets of people who take

Table I. Proximate composition of Dolichos lablab var. vulgaris (g/100g seed flour) ${ }^{\mathrm{a}}$

\begin{tabular}{|c|c|c|}
\hline Component & $\begin{array}{l}\text { Dolichos lablab var. vulgaris } \\
\text { (Dark brown coloured seed coat) }\end{array}$ & $\begin{array}{l}\text { Dolichos lablab var. vulgaris } \\
\text { (Pale brown coloured seed coat) }\end{array}$ \\
\hline Moisture & $7.80 \pm 0.11$ & $6.98 \pm 0.07$ \\
\hline Crude Protein (Kjeldahl N× 6.25) & $21.34 \pm 0.21$ & $22.30 \pm 0.26$ \\
\hline Crude lipid & $5.64 \pm 0.09$ & $5.32 \pm 0.03$ \\
\hline Total dietary fibre (TDF) & $6.66 \pm 0.06$ & $6.23 \pm 0.03$ \\
\hline Ash & $4.26 \pm 0.03$ & $4.01 \pm 0.01$ \\
\hline Nitrogen free Extractives (NFE) & 62.10 & 62.05 \\
\hline Calorific value (KJ $\left.100 \mathrm{~g}^{-1} \mathrm{DM}\right)$ & 1606.08 & 1609.21 \\
\hline
\end{tabular}

${ }^{\mathrm{a}}$ All the values are means of triplicate determinations expressed on dry weight basis.

\pm denotes standard error.

Robinson (1987) reported that a diet that meets two-thrids of the RDA (Recommended Dietary Allowances) values is considered to be adequate for an individual. Food legumes have been recognized as important sources of several mineral in India diets (Gopalan et. al., 1978). diuretics to control hypertension and suffer from excessive excretion of potassium through the body fluid (Siddhuraju et. al., 2001). Both the investigated samples of Dolichos lablab var. vulgaris contained high levels of sodium, calcium, phosphorus, magnesium and iron when compared with

Table II. Mineral composition and Vitamins (niacin and ascorbic acid) of Dolichos lablab var. vulgaris (mg/100g seed flour $)^{\mathrm{a}}$

\begin{tabular}{lcc}
\hline Component & $\begin{array}{c}\text { Dolichos lablab var. vulgaris } \\
\text { (Dark brown coloured seed coat) }\end{array}$ & $\begin{array}{c}\text { Dolichos lablab var. vulgaris } \\
\text { (Pale brown coloured seed coat) }\end{array}$ \\
\hline Sodium & $36.80 \pm 0.09$ & $28.24 \pm 0.19$ \\
Potassium & $1888.01 \pm 1.38$ & $1936.16 \pm 2.46$ \\
Calcium & $268.56 \pm 0.31$ & $236.12 \pm 0.28$ \\
Magnesium & $108.04 \pm 0.17$ & $98.20 \pm 0.11$ \\
Phosphorus & $238.12 \pm 0.24$ & $256.07 \pm 0.36$ \\
Iron & $17.20 \pm 0.06$ & $14.21 \pm 0.07$ \\
Copper & $1.21 \pm 0.04$ & $0.098 \pm 0.01$ \\
Zinc & $2.24 \pm 0.03$ & $1.96 \pm 0.03$ \\
Manganese & $1.36 \pm 0.01$ & $1.56 \pm 0.02$ \\
Na/K & 0.019 & 0.015 \\
Ca/P & 1.13 & 0.92 \\
Niacin & $26.21 \pm 0.14$ & $29.30 \pm 0.16$ \\
Ascorbic acid & $34.01 \pm 0.17$ & $31.26 \pm 0.13$ \\
\hline
\end{tabular}

\footnotetext{
${ }^{\mathrm{a}}$ All the values are means of triplicate determinations expressed on dry weight basis.
}

\pm denotes standard error. 
Phaseolus vulgaris, P. limensis, Vigna unguiculata, Pisum sativum, Lens culinaris and Cicer arietinum (Meiners et. al., 1976). The zinc, copper and manganese content were found to be higher than the Vigna aconitifolia (Tresina and Mohan, 2011). The ratios of sodium to potassium $(\mathrm{Na} / \mathrm{K})$ and calcium to phosphorus $(\mathrm{Ca} / \mathrm{P})$ are also shown in Table II. $\mathrm{Na} / \mathrm{K}$ ratio in the body is of great concern for prevention of high blood pressure $\mathrm{Na} / \mathrm{K}$ ratio less than one is recommended. Hence, in the present study, all the seed probably reduce high blood pressure disease because they had $\mathrm{Na} / \mathrm{K}$ less than one. Modern diets which are rich in animal proteins and phosphorus may promote the loss of calcium in the urine (Shills and Young, 1988). This had led to the concept of the $\mathrm{Ca} / \mathrm{P}$ ratio. If the $\mathrm{Ca} / \mathrm{P}$ ratio is low (low calcium, high phosphorus intake), more than the normal amount of calcium may be loss in the urine, decreasing the calcium level in bones. Food is considered "good" if the ratio is above 1 and "poor" if the ratio is less than 0.5 (Nieman et. al., 1992). The $\mathrm{Ca} / \mathrm{P}$ ratio in the present study ranged between 0.92 to 1.13 indicating they would serve as good sources of minerals for bone formation.

Ascorbic acid that is vitamin $\mathrm{C}$, is an essential nutrient for man as he lacks the capacity to synthesis it like many other pruriens, Phaseolus mungo, Vigna catjang and Vigna species (Rajalakshmi and Geervani, 1994); Vigna unguiculata subsp cylindrica (Arinathan et. al., 2009) and Vigna species (Tresina and Mohan, 2011). The investigated tribal pulses also registered higher level of ascorbic acid content than Cicer arietinum (Fernandez and Berry, 1988); Teramnus labialis (Arinathan et. al., 2009); Vigna mungo varieties (Tresina et. al., 2010) and Vigna species (Tresina and Mohan, 2011).

In the samples investigated, albumin and globulins (5.83$6.58 \%$ and $11.63-12.19 \%$ respectively) constitute the major bulk of the proteins (Table III) as in most legume reported earlier (Tresina et. al., 2010; Murthy, 2011; Murthy and Emmanuel, 2011). The amino acid profiles of the purified seed proteins and the essential amino acid score are presented in Table IV. The content of essential amino acid except tryptophan in the presently investigated Dolichos lablab var. vulgaris (both the samples) was found to be higher compared to the FAO/WHO (1991) requirement pattern. In the presently investigated seed samples registered higher amounts of in vitro protein digestibility than that of earlier investigations in the seeds of Vigna mungo varieties (Tresina et. al., 2010) and Lablab purpuries varieties $\mathrm{CO}_{1}$ and $\mathrm{CO}_{12}$ (Kala et. al., 2010).

Table III. Data on total (free) proteins and protein fractionation of seed flour of Dolichos lablab var. vulgarisa

\begin{tabular}{lcccc}
\hline Fraction & \multicolumn{2}{c}{$\begin{array}{c}\text { Dolichos lablab var. vulgaris } \\
\text { (Dark brown coloured seed coat) }\end{array}$} & $\begin{array}{c}\text { Dolichos lablab var. vulgaris } \\
\text { (Pale brown coloured seed coat) }\end{array}$ \\
\hline & $\mathrm{g} / 100 \mathrm{~g}$ seed flour & $\mathrm{g} / 100 \mathrm{~g}$ Protein & $\mathrm{g} / 100 \mathrm{~g}$ seed flour & $\mathrm{g} / 100 \mathrm{~g}$ Protein \\
Total protein (free protein) & $18.48 \pm 0.14$ & 100 & $19.96 \pm 0.24$ & 100 \\
Albumins & $5.83 \pm 0.06$ & 31.55 & $6.58 \pm 0.09$ & 32.96 \\
Globulins & $11.63 \pm 0.03$ & 62.93 & $12.19 \pm 0.11$ & 61.07 \\
Prolamins & $0.54 \pm 0.01$ & 2.92 & $0.61 \pm 0.01$ & 3.06 \\
Glutelins & $0.48 \pm 0.01$ & 2.60 & $0.58 \pm 0.03$ & 2.91 \\
\hline
\end{tabular}

${ }^{\mathrm{a}}$ All the values are means of triplicate determinations expressed on dry weight basis.

\pm denotes standard error.

animal species. Ascorbic acid is a strong reducing agent. It is involved in collagen synthesis, bone and teeth calcification and many other reactions in the body as a reducing agent. Nicotinic acid (also called niacin) is a vitamin intimately connected with several metabolic reactions. It takes part as a component of coenzyme in oxidative reactions and is concerned with metabolism of carbohydrate, fats and proteins. The presently investigated legumes Dolichos lablab var. vulgaris exhibited the highest level of niacin content (Table II) which was found to be higher than that of an earlier report in Cajanus cajan, Dolichos lablab, D. biflorus, Mucuna
The fatty acid composition of the total seed lipids of Dolichos lablab var. vulgaris (both the samples) were given in Table V. The data revealed that, both the seed lipids were rich in unsaturated fatty acids (66.78-69.08\%) and had very high contents of linoleic acid (40.36-41.62\%). These values are nutritionally desirable and also higher than certain legumes Vigna radiata (Salunkhe et. al., 1982); Phaseolus vulgaris (Omogbai, 1990); Vigna mungo varieties (Tresina et. al., 2010) Vigna aconitifolia and Vigna unguiculata subsp unguiculata (Tresina and Mohan, 2011). The palmitic acid content of Dolichos lablab var. vulgaris (both the samples) 
Table IV. Amino acid profiles of acid-hydrolysed, purified total seed proteins of Dolichos lablab var. vulgarisa ${ }^{\text {a }}$

\begin{tabular}{|c|c|c|c|c|c|}
\hline Amino acid & $\begin{array}{c}\text { Dolichos lablab } \\
\text { var. vulgaris } \\
\text { (Dark brown } \\
\text { coloured seed coat) }\end{array}$ & $\begin{array}{c}\text { Essential } \\
\text { amino acid } \\
\text { score }\end{array}$ & $\begin{array}{c}\text { Dolichos lablab } \\
\text { var. vulgaris } \\
\text { (Pale brown coloured } \\
\text { seed coat) }\end{array}$ & $\begin{array}{l}\text { Essential } \\
\text { amino acid } \\
\text { score }\end{array}$ & $\begin{array}{l}\mathrm{FAO} / \mathrm{WHO}(1991) \\
\text { requirement pattern }\end{array}$ \\
\hline Glutamic acid & 15.63 & & 15.12 & & \\
\hline Aspartic acid & 13.68 & & 14.36 & & \\
\hline Serine & 5.21 & & 5.06 & & \\
\hline Threonine & 5.01 & 147.35 & 5.31 & 156.18 & 3.4 \\
\hline Prolien & 4.32 & & 3.98 & & \\
\hline Alanine & 4.12 & & 4.24 & & \\
\hline Glycine & 4.36 & & 4.84 & & \\
\hline Valine & 4.98 & 142.29 & 5.16 & 147.43 & 3.5 \\
\hline Cystine & 0.38 & 63.60 & 0.46 & 63.20 & 2.5 \\
\hline Methionine & 1.21 & & 1.12 & & \\
\hline Isoleucine & 4.56 & 162.86 & 4.84 & 172.86 & 2.8 \\
\hline Leucine & 7.36 & 11.52 & 7.86 & 119.09 & 6.6 \\
\hline Tyrosine & 4.01 & 147.46 & 4.36 & 157.14 & 6.3 \\
\hline Phenylalamine & 5.28 & & 5.54 & & \\
\hline Lysine & 7.65 & 131.90 & 7.02 & 121.03 & 5.8 \\
\hline Histidine & 3.54 & 186.32 & 3.74 & 196.84 & 1.9 \\
\hline Tryptophan & 0.94 & 85.45 & 0.88 & 80.00 & 1.1 \\
\hline Arginine & 5.62 & & 5.39 & & \\
\hline
\end{tabular}

${ }^{\mathrm{a}}$ All values are of single determinations.

was higher than the other legumes such as Vigna radiata (Salunkhe et. al., 1982); V. unguiculata, Phaseolus vulgaris (Omogbai, 1990); Glycine max (Ologhobo and Fetuge, 1984) and Vigna species (Tresina and Mohan, 2011).

Legumes commonly consist of toxic factors, which decrease the digestibility and prevent bioavailability of nutrients. For this reason, preliminary evaluations of some of these factors in raw pulses were made (Table VI). The content of total free phenolics of currently investigated pulses appears to be lower than the earlier reports in Canavalia gladiata,
Neonotonia wightii var. coimbatorensis, Vigna trilobata, Vigna unguiculata subsp unguiculata, Vigna radiata var. sublobata, Dolichos trilobus, Rhynchosia cana, R. shaveolens, Teramnus labialis, $V$. unguiculata subsp cylindrica (Arinathan et. al., 2003; 2009); V.mungo varieties (Tresina et. al., 2010) Vigna species (Tresina and Mohan, 2011) and Cajanus albicans (Murthy, 2011). The tannin content of the investigated samples were relatively lower than the Phaseolus vulgaris, Cajanus cajan (Sangronis and Machado, 2007); Vigna radiata, V. mungo (Kakati et. al., 2010); Phaseolus aureus, Cajanus cajan, Lens esculenta and

Table V. Fatty acid profile of the seed lipids of Dolichos lablab var. vulgaris $(\mathrm{g} / 100 \mathrm{~g})^{\mathrm{a}}$

\begin{tabular}{lcc}
\hline Fatty acid & $\begin{array}{c}\text { Dolichos lablab var. vulgaris } \\
\text { (Dark brown coloured seed coat) }\end{array}$ & $\begin{array}{c}\text { Dolichos lablab var. vulgaris } \\
\text { (Pale brown coloured seed coat) }\end{array}$ \\
\hline Palmitic acid (C16:0) & 28.32 & 27.30 \\
Stearic acid (C18:0) & 3.10 & 2.84 \\
Oleic acid (C18:1) & 14.28 & 14.56 \\
Linoleic acid (C18:2) & 40.36 & 41.62 \\
Linolenic acid (C18:3) & 12.14 & 12.90 \\
Others & 1.80 & 0.78 \\
\hline
\end{tabular}

\footnotetext{
${ }^{\text {a }}$ All values are of two determinations.
} 
Table VI. Data on in vitro protein digestibility (IVPD) and antinutritional factors o Dolichos lablab var. vulgaris ${ }^{\mathrm{a}}$

\begin{tabular}{|c|c|c|}
\hline Components & $\begin{array}{l}\text { Dolichos lablab var. vulgaris } \\
\text { (Dark brown coloured seed coat) }\end{array}$ & $\begin{array}{l}\text { Dolichos lablab var. vulgaris } \\
\text { (Pale brown coloured seed coat) }\end{array}$ \\
\hline In vitro protein digestibility $(\%)^{\mathrm{a}}$ & $66.34 \pm 1.21$ & $67.60 \pm 0.76$ \\
\hline Total free phenolics ${ }^{\mathrm{b}} \mathrm{g} / 100 \mathrm{~g}$ & $0.61 \pm 0.03$ & $0.52 \pm 0.04$ \\
\hline Tannins ${ }^{\mathrm{b}} \mathrm{g} / 100 \mathrm{~g}$ & $0.17 \pm 0.02$ & $0.19 \pm 0.01$ \\
\hline L-DOPA ${ }^{b} g / 100 g$ & $0.91 \pm 0.11$ & $0.87 \pm 0.12$ \\
\hline Phytic acid ${ }^{\mathrm{b}} \mathrm{g} / 100 \mathrm{~g}$ & $413.26 \pm 2.46$ & $388.21 \pm 2.14$ \\
\hline Hydrogen cyanide ${ }^{b} \mathrm{mg} / 100 \mathrm{~g}$ & $0.31 \pm 0.01$ & $0.24 \pm 0.02$ \\
\hline Trypsin inhibitora(TIU $\mathrm{mg}^{-1}$ protein) & $29.28 \pm 0.07$ & $31.24 \pm 0.14$ \\
\hline \multicolumn{3}{|l|}{ Oligosaccharides $^{\mathrm{b}} \mathrm{g} / 100 \mathrm{~g}$} \\
\hline Raffinose & $0.58 \pm 0.06$ & $0.41 \pm 0.03$ \\
\hline Stachyose & $1.76 \pm 0.03$ & $1.66 \pm 0.09$ \\
\hline Verbascose & $1.20 \pm 0.04$ & $1.24 \pm 0.03$ \\
\hline \multicolumn{3}{|c|}{ Phytohaemagglutinating activity ${ }^{\mathrm{a}}\left(\mathrm{Hu} \mathrm{mg}^{-1}\right.$ protein $)$} \\
\hline A group & 34 & 42 \\
\hline B group & 164 & 174 \\
\hline O group & 29 & 33 \\
\hline
\end{tabular}

${ }^{\mathrm{a}}$ All values of two independent experiments

${ }^{b}$ All values are of means of triplicate determination expressed on dry weight basis

\pm Standard error

Cicer arietinum (Khandelwal et. al., 2010). Phenolics and tannins are known to inhibit activities of digestive enzymes and hence, the presence of even low levels of tannins and phenolics is not desirable from a nutritional point of view. However, in legumes, the soaking and cooking process is known to reduce phenolics and tannins significantly (Vadival and Pugalenthi, 2008). Recently phenolics have antioxidative, antiallergic, antidiabetic, anticarcinogenic, antimicrobial, antimutagenic and anti-inflammatory activities. (Arts and Hollman, 2005; Scalbert et. al., 2005). In the currently investigated samples, the content of the non-protein amino acid, L-DOPA is low compared with those of the tribal pulses such as Entada rheedi, Vigna radiata var. sublobata and Vigna unguiculata subsp unguiculata (Arinathan et. al., 2003; 2009) Paracalyx scariosus (Murthy and Rao, 2009) and Rhynchosia bracteata (Murthy and Emmanuel, 2011).

Phytic acid has an antinutritional property because of its ability to lower the bioavailability of essential minerals and to form a complex with protein, thereby inhibiting the enzymatic digestion of investigated protein (Nolan and Duffin, 1987). Phytic acid content of investigated seed samples was found to be low when compared with that of some commonly consumed legumes, Lablab purpureus (Osman, 2007);
Vigna radiata and $V$. mungo (Kakati et. al., 2010) and more or less equal to the Vigna mungo varities Tmv1 and Vamban 1 (Tresina et. al., 2010). Hydrogen cyanide is known to cause acute or chronic toxicity. The content of HCN level in the presently investigated legume was far below the level i.e. $36 \mathrm{mg} / 100 \mathrm{~g}$ (Oke, 1969) and comparable with those of Dolichos trilobus, Rhynchosia cana R.suaveolens, Teramnus labialis, Vigna radiata var. sublobata, Vigna unguiculata subsp cylindrica (Arinathan et. al., 2009); Vigna aconitifolia and Vigna unguiculata subsp unguiculata (Tresina and Mohan, 2011). The trypsin inhibitor activities of the presently studied samples were higher than that of Vigna radiata, Phaseolus vulgaris (Mohamed et. al., 2011) and Vigna species (Tresina and Mohan, 2011). Stachyose seems to be the principle oligosaccharide of investigated Dolichos lablab var. vulgaris (both the samples). It was in conformity with the earlier reports in Cicer arietinum (Alajaji and El-Adawy, 2006); Sphenostylis stenocarpa, Voandzeia subterranean, Phaseolus vulgaris, P. lunatus, Cajanus cajan, Canavalia ensiformis (Apata, 2008); Lablab purpures varieties (Kala et. al., 2010); Vigna aconitifolia and Vigna unguiculata subsp unguiculata (Tresina and Mohan, 2011). The lectin (Phytoheamagglutinating activity) of seed samples exhibited 
a high level of agglutination activity specifically in 'B' group compared to other two blood groups ' $\mathrm{A}$ ' and ' $\mathrm{O}$ '. This is in good agreement with earlier reports in the Vigna aconitifolia and Vigna unguiculata subsp unguiculata (Tresina and Mohan, 2011).

Investigations on the nutritional and antinutritional qualities of seeds of Dolichos lablab var. vulgaris are scanty. On the basis of the above findings, it is concluded that the tribal pulse investigated seem to be a good source of protein, essential amino acids, essential fatty acids, minerals and vitamins. All the antinutritional factors reported except LDOPA are heat liable. Hence they can be removed by wet or dry thermal treatment. It has been demonstrated that, the level of L-DOPA is significantly eliminated by soaking and autoclaving (Vadivel and Pugalenthi, 2008). The presently studied tribal pulses exhibit high level of nutrients, besides in vitro protein digestibility and low level of antinutritional factors. From these chemical investigations it is concluded that, the presently investigated tribal pulses can be used as protein source to curtail with problem of protein deficiency in most of the developing countries which may result in many child killer diseases. After conducting toxicology/animal feeding experiments, these little known tribal pulses may be recommended for large scale consumption as an alternative potential source of protein.

\section{Acknowledgement}

One of the author, V. Kalpanadevi wish to acknowledge the University Grant Commission (UGC), New Delhi, India for financial assistance under the grant, Rajiv Gandhi National Fellowship.

\section{References}

Alajaji SA and El-Adawy TA (2006), Nutritional composition of chickpea (Cicer arietinum L.) as affected by microwave cooking and other traditional cooking methods, J. Food. Comp. Anal. 19: 806-812.

Almedia NG, Calderon de la Barca AM and Valencia ME (1991), Effect of different heat treatments on the antinutritional activity of Phaseolus vulgaris (variety ojode Carbra) lution, J. Agri. Food Chem. 39: 1627 1630.

AOAC (2005), Official Methods of Analysis (18th edn.). Association of Official Analytical Chemists.
Washington. DC.

Apata DF (2008), Effects of cooking methods on available and unavailable carbohydrates of some tropical grain legumes, Afri. J. Biotech. 7: 2940-29451.

Arinathan V, Mohan VR and De Britto AJ (2003), Chemical composition of certain tribal pulses in South India, Int. J. Food Sci. Nutri. 54: 209-217.

Arinathan V, Mohan VR, Maruthupandian A and Athiperumalsami T (2009), Chemical evaluation of raw seeds of certain tribal pulses in Tamil Nadu, India, Trop. Subtrop. Agroecosys, 10: 287-294.

Arora RK, Chandel KPS, Joshi BS and Pant KC (1980), Rice bean; Tribal pulse of Eastern India, Econ. Bot. 34: 260263.

Arts IC and Hollman PC (2005), Polyphenols and disease risk in epidemiological studies, Amer. J. Clin. Nutr. 81: 3175-3255.

Basha SMM, Cherry JP and Young CT (1976), Changes in free amino acids, Carbohydrates and proteins of maturity seeds from various peas (Arachis hypogaea) cultivars, Cereal Chem. 53: 583 - 597.

Bello-Perez LA, Sayago-Ayerdi SG, Chavez-murillo CE, Agama-Acevedo E and Tovar J (2007), Proximal composition and in vitro digestibility of starch in Lima bean (Phaseolus lunatus) varities, J. Sci. Food. Agri. 87: 2570-2575.

Brain KR (1976), Accumulation of L-DOPA in cultures from Mucuna pruriens, Plant Sci. Lett. 7: 157-161.

Bray HG and Thorne WV (1954), Analysis of phenolic compounds methods. Biochem. Analyst, 1: 27-52.

Burns RB (1971), Methods of estimation of tannin in the grain, sorghum, Agronomy J. 63: 511 -512.

Dickman SR and Bray RH (1940), Colorimetric determination of phosphate, Industrial Eng. Chem. Anal. Edu. 12: 665-668.

FAO/WHO (1991), Protein Quality Evaluation. Food and Agricultural organization of the United Nations: Roe, Italy, pp.1- 66 .

Fernandez ML and Berry JW (1988), Nutritional evaluation of chickpea and germinated chickpea flours, Plant Food Hum. Nutr. 38: 127-134. 
Folch J, Lees M and Solane-Stanly GM (1957), A simple method for the isolation and purification of total lipids from animal tissues, J. Biol. Chem. 226: 497 - 506.

Gopalan C, Ramasastri BV and Balasubramanian SC (1978), Nutritive value of Indian Foods. Indian Council of Medical Research, Hyderabad India.

Hsu HW, Vavak DL, Satterlee LD and Miller GA (1977), A multi-enzyme technique for estimating protein digestibility, J. Food Sci. 42: 1269 - 1271.

Humphries EC (1956), Mineral composition and ash analysis In: Peach K. and M.V. Tracey (eds.) Modern Methods of Plant Analysis Vol.1, Springer-Verlag, Berlin, pp: 468-502.

Issac RA and Johnson WC (1975), Collaborative study of wet and dry techniques for the elemental analysis of plant tissue by Atomic Absorption Spectrophotometer, J. Assoc. Off. Anal. Chem. Int. 58: 376-38.

Jackson ML (1967), Cyanide in Plant tissue. In: Soil Chemical Analysis. Asia Publishing House New Delhi India. pp. 337.

Kakade ML, Rackis JJ, McGhce JE and Puski G (1974), Determination of trypsin inhibitor activity of soy products: a collaborative analysis of an improved procedure, Cereal Chem. 51: 376 -38.

Kakati P, Deka SC, Kotoki D and Saikia S (2010), Effect of traditional methods of processing on the nutrient contents and some antinutritional factors in newly developed cultivars of green gram [Vigna radiata (L.) Wilezek] and black gram [Vigna mungo (L.) Hopper] of Assam, India. Int. Food. Res. J. 17: 377-384.

Kala KB, Tresina Soris P, Mohan VR. and Vadivel V (2010), Nutrient and chemical evaluation of Lablab purpureus (L.) Sweet. Adv. Biores. 1: 44-53.

Khandelwal S, Udipi SA and Ghugre P (2010), Polyphenol and tannins in Indian pulses: Effects of soaking, germination and pressure cooking, Food Res. Int. 43: 526530 .

Khatoon N and Prakash J (2006), Nutritional quality of microwave-cooked and pressure-cooked legumes, Int. J. Food Sci. Nut. 55: 441-448.

Li BW and Cardozo MS (1994), Determination of total dietary fiber in foods and products with little or no starch, non-enzymatic gravimetric method: collaborative study. J. Ass.Off. Anal. Chem. Int. 77: 687 -689.

Liddell HF and Saville B (1959), Colorimetric determination of cysteine, Analyst, 84: 133 -137.

Lowry OH, Rorebrough NJ, Farr AL and Randall RJ (1951), Protein measurement with folin phenol reagent, J. Biol. Chem. 193: 265 - 275.

Maikhuri RK, Nautiyal MC and Khali MP. (1991), Lesser known crops of foods value in garhwal Himalaya and a strategy to conserve them, FAO/IBPGR Plant Genet. Resou. Newslett. 80: 33-36.

Meiners CR, Derise NL, Lau HC, Crews MG, Ritchey SJ and Murphy EW (1976), Proximate composition and yield of raw and cooked dry legumes, J. Agric. Food Chem. 24: 1122-1126.

Metcalfe LD, Schemitz AA and Pelka JR (1966), Rapid preparation of fatty acid esters from lipids for gas chromatographic analysis, Anal Chem. 38: 514 - 515.

Mohamed KR, Gibriet AY, Ramy MH, Abu- Salem FM and Abou-Arab EA (2011), Influence of legume processing treatments individually or in combination on their trypsin inhibitor and total phenolic contents, Austr. J. Bas. App. Sciences. 5: 1310-1322.

Muller HG and Tobin G (1980), Nutrition and food processing, London: Croom Helm Ltd.

Murthy KSR and Emmanuel S (2011), Nutritional and antinutritional properties of the underexploited Wild legume Rhynchosia bracteata Benth, Bangl. J. Sci. Ind. Res. 46: 141-146.

Murthy KSR and RAO KRSS (2009), Chemical composition and nutritional evaluation of Paracalyx scariosus (Roxb.) Ali a wild relative of Cajanus from Southern Peninsular India, Trop. Subtrop. Agroecosys. 10: 121127.

Murthy KSR (2011), Nutritional potential and biochemical compounds in Cajanus albicans (Wight \& arn) van der maesan for food and agriculture, J. Agric. Technol. 7: 161-171.

Nieman DC and Batterworth Nieman CN (1992), Nutrition. WMC. Brown Publishers, Dubugue, USA. pp.237312. 
Nolan K. and Duffin PA (1987), Effect of phytate on mineral bioavailability. In vitro studies on $\mathrm{Mg}^{2+}, \mathrm{Ca}^{2+}, \mathrm{Fe}^{2+}$, $\mathrm{Cu}^{2+}$ and $\mathrm{Zn}^{2+}$ solubilities in the presence of phytate, $J$. Sci. Food. Agric. 40: 79-83.

NRC/NAS (1980). National Research Council Committee on Dietary Allowances. Recommended Dietary Allowances 9th edn. National Academy of Science Press. Washington, DC. USA.

Oke OL (1969), The role of hydrocyanic acid in nutrition. World Rev. Nutr. Diete. 11: 118-147.

Ologhobo AD and Fetuga BL (1984), Distribution of phosphorus and phytate in some Nigerian varities of legumes and some effects of processing, J. Food Sci. 49: 199-201.

Omogbai FE (1990), Lipid composition of tropical seeds used in the Nigerian diet, J. Sci. Food. Agric. 50: 253 255.

Osman MA (2007), Effect of different processing methods on nutrient composition, Anti-nutritional factors and in vitro protein digestibility of Dolichos lablab bean (Lablab purpureus (L.) Sweet.), Pak. J. Nutr. 6: 299303.

Rajyalakshmi P and Geervani P (1994), Nutritive value of the foods cultivated and consumed by the tribals of South India. Plant Foods. Hum. Nutr. 46: 53-61.

Rama Rao MV, Tara MR and Krishnan CK (1974), Colorimetric estimation of tryptophan content of pulses, J. Food Sci. Technol. (Mysore), 11: 13- 216.

Rao BSN, Deosthale YG and Pant CK (1989), Nutritive Value of Indian Foods. Hyderabad, India: National Institute of Nutrition, Indian Council of Medical Research.

Robinson DR (1987), Food Biochemistry and Nutritional value. Burn mill, long-man scientific and technology, Haslow, England, pp327-328.

Sadasivam S and Manickam A (1996), Biochemical methods, New age International (P) limited publishers, New Delhi, India.

Salunkhe DK, Sathe SK and Reddy NR (1982), Legume lipids. In Chemistry and Biochemistry of Legumes, ed. S. K. Arora. Oxford \& IBH, New Delhi, 51-109.
Salunkhe DK., Kadam SS and Chavan Jk. (1985), Chemical composition. In: DK. Salunkhe, SS. Kadam and JK. Chavan (eds). Post harvest Biotechnology of Food legumes. CRC press Inc: Boca Rabon, FL. pp29-52.

Sangronis E and Machado CJ (2007), Influence of germination on the nutritional quality of Phaseolus vulgaris and Cajanus cajan. J. Food Sci. Technol. (LWT), 40: 116-120.

Scalbert A, Monach C, Morand C, Remesy C and Jimenez L (2005), Dietary polyphenols and the prevention of disease, Crit. Rev. Food Sci. Nutr. 45: 287-306.

Shills MEG and Young VR (1988), Modern nutrition in health and disease. In Nutrition, D.C. Nieman, D.E. Buthepodorth and C.N. Nieman (eds). WmC. Brown publishers Dubugue, USA. pp: 276-282.

Siddhuraju P, Becker K and Makkar HPS (2001), Chemical composition, protein fractionation, essential amino acid potential and antimetabolic constituents of an unconventional legume, Gila bean (Entada phaseoloides Merrill.) seed kernel, J. Sci. Food. Agric. 82: $192-202$.

Siddhuraju P, Vijayakumari K and Janardhanan K (1996), Chemical composition and protein quality of the little known legume, velvet bean [Mucuna pruriens (L.) DC.]. J. Agric. Food Chem. 44: 2636 -2641.

Somiari RT and Balogh E (1993), Effect of soaking, cooking and alpha- galactoside treatment on the oligosaccharide content of cowpea flours, J. Sci. Food. Agric. 61: $339-343$.

Spies JR and Chamber DC (1949), Chemical determination of tryptophan in proleins, Anal. Chem. 21: 1249 - 1266.

Srivastava RP and Ali M (2004), Nutritional quality of common pulses. Indian Institute of Pulses Research, Kanpur, India.

Tan NH, Rahim ZHA, Khor HT and Wong KC (1983), Winged bean (Psophocarpus tetragonolobus). Tannin level, phytate content and haemagglutinating activity, J. Agric. Food Chem. 31: 916 - 917.

Tanaka M, Thanankul D, Lee TC and Chichester LO (1975), A simplified method for the quantitative determination of sucrose, raffinose and stachyose in legume seeds, $J$. Food Sci. 40: 1087 - 1088. 
Tresina PS, Kala KB, Mohan VR and Vadivel V (2010). The biochemical composition and nutritional potential of three varieties of Vigna mungo (L.) Hepper. Adv. Biores. 1: 6-16.

Tresina PS and Mohan VR (2011), Effect of gamma irradiation on physicochemical properties, proximate composition, vitamins and antinutritional factors of the tribal pulse Vigna unguiculata subsp. unguiculata, International J. Food Sci. Tech. 46: 1739-1746.

Vadivel V and Janardhanan K (2000), Chemical composition of the underutilized legume Cassia hirsuta L. Plant Foods Hum. Nutr. 55: 369-381.
Vadivel V and Pugalenthi M (2008), Removal of antinutritonal substances and improvement in the protein digestibility of velvet bean (Mucuna pruriens) seed during processing. J. Food Sci. Tech. 45: 242-246.

Wheeler EL and Ferrel RE (1971), A method for phytic acid determination in wheat and wheat fractions, Cereal Chem. 48: 312 - 320.

Received: 27 November 2012; Revised: 21 January 2013; Accepted: 24 March 2013. 